\title{
PEMBELAJARAN AQIDAH AKHLAK DENGAN STRATEGI INKUIRI UNTUK MEMBENTUK KARAKTER PESERTA DIDIK DI MADRASAH IBTIDAIYAH (MI) MUHAMMADIYAH TURUS KABUPATEN KLATEN
}

\author{
Diah Novita Fardani \\ IAIN Surakarta \\ Email: diahnovita.novy@gmail.com
}

\begin{abstract}
Abstrak
Pendidikan karakter merupakan aspek yang sangat penting di era perkembangan zaman sekarang ini. Tujuan dari penelitian ini yaitu membentuk karakter peserta didik sejak dini. Dengan adanya karakter yang telah tertanam dalam diri peserta didik akan membentengi dirinya dari bahaya perubahan zaman kelak yang akan terjadi. Penelitian ini dilakukan dengan metode kualitatif, pengumpulan data dilakukan dengan cara observasi dan wawancara. Hasil dari penelitian ini yaitu bahwa pembelajaran Aqidah Akhlak dengan strategi inkuiri dapat membentuk karakteristik peserta didik.
\end{abstract}

Kata Kunci: Karakter, Aqidah Akhlak, Strategi Inkuiri.

\section{Abstract}

Character education is a very important aspect in the current era of development. The purpose of this study is to shape the character of students from an early age. With the character that has been embedded in the students will fortify themselves from the dangers of future changes that will occur. This research was conducted with qualitative methods, data collection was done by observation and interview. The results of this research are that learning Aqidah Akhlak with inquiry strategies can shape the characteristics of students.

Keywords: Character, Aqidah Akhlak, Inquiry Strategy.

\section{Pendahuluan}

Madrasah merupakan lembaga pendidikan setaraf dengan sekolah. Sekolah merupakan salah satu kebutuhan masyarakat yang dapat meningkatkan taraf hidup masyarakat menjadi lebih baik. Sekolah dijadikan sebagai tempat berlangsungnya kegiatan belajar mengajar yang dilakukan oleh pendidik dan peserta didik. Keberadaan sekolah atau madrasah sangat penting dalam melancarkan jalannya proses belajar mengajar antara pendidik dan peserta didik untuk mencapai suatu tujuan yang telah ditetapkan. Dengan demikian keberadaan lembaga pendidikan, baik itu berstatus swasta maupun negeri sangatlah penting.

Dalam mencapai suatu tujuan tentunya harus ada persiapan dan juga proses yang panjang dalam mencapai tujuan tersebut, sehingga dapat mengurangi terjadinya hambatan. Seperti halnya dalam pendidikan dan juga pengajaran, harus dipersiapkan komponen-komponen yang menunjang tercapainya tujuan dengan sedemikian rupa agar tujuan tercapai dengan maksimal, seperti RPP, silabus, strategi dan metode mengajar, dan lain-lain.

Adanya perencanaan sebelum jalannya proses belajar mengajar dilaksanakan tersebut 
akan menjadikan proses belajar mengajar yang berlangsung di dalam kelas akan terarah berjalan sesuai dengan alur yang telah dirancang sebelumnya. Adanya perencanaan ini menjadikan proses belajar mengajar menjadi efektif dan efisien dalam mencapai suatu tujuan yang telah ditetapkan. Begitu pula dengan strategi pembelajaran, yang mana strategi pembelajaran juga harus diperhatikan ketika proses belajar mengajar berlangsung.

Pembelajaran dikatakan berhasil apabila peserta didik memahami materi yang telah diajarkan oleh pendidik. Dikatakan pendidik profesional jika dapat menjadikan peserta didik paham dengan materi yang sedang dibahas. Peserta didik dapat memahami materi dengan baik apabila pembelajaran dilaksanakan dengan strategi yang tepat. Dengan demikian, seorang pendidik harus mengetahui strategi yang tepat dalam mengajarkan materi kepada peserta didiknya,

Akan tetapi banyak pendidik yang tidak memperhatikan strategi yang tepat dalam mengajarkan materi kepada peserta didik. Kebanyakan para pendidik hanya menggunakan satu strategi dalam proses belajar mengajar. Materi apapun yang diajarkan kebanyakan hanya menggunakan satu strategi pembelajaran atau bahkan hanya menggunakan satu jenis metode pembelajaran saja.

Hal itu akan menyebabkan peserta didik bosan untuk mengikuti mata pelajaran tersebut. Bahkan mereka akan sibuk dengan urusan mereka masing-masing, seperti bicara sendiri saat guru menjelaskan, bermain, dan membuat kegaduhan di dalam kelas. Sehingga mereka tidak memperhatikan penjelasan guru dan tidak paham dengan materi yang diajarkan. Dengan demikian, dalam artikel ini peneliti akan membahas mengenai strategi yang digunakan dalam pembelajaran Aqidah Akhlak.

Mata pelajaran Aqidah Akhlak bukan hanya mata pelajaran yang mengharapkan para peserta didik mampu memahami materinya saja, melainkan mata pelajaran yang mengharapkan agar perserta didik mampu menerapkan materi tersebut dalam kehidupan sehari-hari. Seperti berperilaku baik atau berakhlak mulia, melaksanakan perintah Allah dan menjauhi larangan-Nya, menghormati orang tua, dan lain-lain. Sehingga mata pelajaran Aqidah Akhlak ini bukan hanya menekankan pada aspek pengetahuan saja melainkan juga aspek sikap, baik sikap sosial maupun sikap spiritual.

Pendidikan karakter merupakan salah satu aspek penting yang harus ditanamkan pada diri peserta didik. Karakter haruslah dibentuk sedini mungkin, karena karakter yang telah terbentuk itu akan sulit untuk diubah. Hal ini dilakukan karena mengingat adanya perubahan zaman yang semakin cepat, sehingga banyak terjadi hal-hal negatif yang dilakukan oleh para pelajar, seperti tawuran antar pelajar, geng motor, begal, pergaulan bebas, dan lain sebagainya. Penanaman pendidikan karakter pada peserta didik dapat dilakukan melalui proses pembelajaran Aqidah Akhlak salah satunya yaitu dengan menggunakan strategi inquiry.

Penulisan ini bertujuan untuk membentuk karakter peserta didik agar menjadi peserta didik yang berakhlak mulia dan menjalankan perintah Allah SWT serta menjauhi laranganNya. Dengan mempelajari Aqidah Akhlak diharapkan peserta didik dapat menerapkannya dalam kehidupan sehari-hari. Strategi inquiry diharapkan dapat menjadi salah satu strategi yang efektif dalam pembelajaran Aqidah Akhlak untuk membentuk karakter peserta didik. 
Peneliti memilih MI Muhammadiyah Turus sebagai objek yang diteliti karena di MI tersebut dalam pembelajaran menggunakan strategi yang tepat dalam mengajarkannya. Selain itu di MI tersebut juga sangat mengedepankan pendidikan karakter atau perilaku yang baik dalam kehidupan sehariharinya. Pada MI Muhammadiyah tersebut penanaman karakter sudah ditanamkan sejak dini.

Ada berbagai macam jenis strategi yang digunakan dalam pembelajaran Aqidah Akhlak salah satunya yaitu strategi inkuiri. Penulisan artikel ini akan membahas mengenai pembelajaran Aqidah Akhlak dengan strategi inkuiri untuk membentuk karakter peserta didik di MI Muhammadiyah Turus. Dengan menggunakan strategi inkuiri dalam pembelajaran Aqidah Akhlak ini dapat membentuk karakter peserta didik melalui bimbingan guru di madrasah.

\section{Metode Penelitian}

Penelitian ini dilakukan dengan menggunakan metode penelitian kualitatif. Metode kualitatif ini dilakukan peneliti dengan mengumpulkan data apa adanya yang ada di madarasah yang akan dijadikan sebagain tempat penelitian. Dalam penulisan ini, peneliti melakukan observasi dan pengamatan langsung di lapangan. Penelitian ini dilaksanakan di Madrasah Ibtidaiyah (MI) Muhammadiyah Turus yang terletak di Dukuh Mrisen, Desa Turus, Kecamatan Polanharjo, Kabupaten Klaten, Jawa Tengah.

Teknik pengumpulan data yang dilakukan peneliti yaitu dengan observasi, dokumentasi, dan wawancara. Peneliti melakukan pengamatan secara langsung di lapangan. Peneliti mengamati keadaan atau situasi di MI tersebut, baik dari jumlah guru, jumlah siswa, maupun proses pembelajaran di MI Muhammadiyah tersebut. Hal ini dilakukan sebagai bentuk pengumpulan data guna memperoleh data yang dibutuhkan. Wawancara dilakukan oleh peneliti kepada informan untuk mendapatkan informasi yang diperlukan dalam menyelesaikan tugas pembuatan artikel ilmiah. Jenis wawancara yang dilakukan menggunakan wawancara bebas (tidak terstruktur). Tujuan dari wawancara ini yaitu agar memperoleh data secara mendalam, bukan sekedar jawaban sesuai dengan topik pembahasan saja.

Sumber data diperoleh dari dua jenis sumber data, yaitu sumber data primer dan sumber data sekunder. Sumber data primer yaitu sumber data yang diperoleh secara langsung dapat memberikan informasi kepada peneliti. Sumber data ini dapat diperoleh dari kepala sekolah, guru Aqidah Akhlak, dan peserta didik. Proses pengumpulan data ini dapat diperoleh melalui wawancara. Sedangkan sumber data sekunder adalah sumber data yang diperoleh tidak secara langsung dapat memberikan informasi kepada peneliti karena harus ada pengolahan terlebih dahulu untuk dapat mengetahui informasi dari data yang diperoleh tersebut. Hal ini dapat diperoleh melalui dokumentasi mengenai data tenaga pendidik dan kependidikan di madrasah tersebut, profil sekolah, struktur ketenagakerjaan, dan lainlain.

Subjek penelitian dalam penulisan artikel ilmiah ini yaitu guru Aqidah Akhlak dan siswa kelas satu di MI Muhammadiyah Turus. Sedangkan informan dalam penelitian ini yaitu kepala sekolah dan guru Aqidah Akhlak di MI Muhammadiyah Turus. Peneliti memperoleh informasi melalui kegiatan wawancara yang dilakukan dengan guru Aqidah Akhlak di MI tersebut. 


\section{Hasil dan Pembahasan}

Pembelajaran adalah proses penyampaian ilmu pengetahuan yang menjadikan seseorang dari yang pada awalnya belum tahu menjadi tahu. Pembelajaran dapat pula disebut sebagai proses belajar. Pembelajaran dilakukan oleh pendidik dan peserta didik pada susatu tempat dan membahas mengenai tema tertentu. Tujuan dari adanya pembelajaran yaitu adanya suatu perubahan yang terjadi oleh pembelajar. Perubahan tersebut terjadi setelah adanya proses pembelajaran.

Aqidah Akhlak merupakan salah satu rumpun pelajaran Pendidikan Agama Islam. Mata pelajaran Aqidah Akhlak diajarkan pada lembaga pendidikan yang kurikulumnya berbasis Islam. Sebagai contoh lembaga pendidikan yang mengajarkan mata pelajaran Aqidah Akhlak yaitu madrasah, sekolah Islam terpadu, dan lain-lain.

Mata pelajaran Aqidah Akhlak merupakan mata pelajaran yang didalamnya terkandung nilai-nilai yang berhubungan dengan keimanan kepada Allah dan perilaku terpuji atau akhlak mulia. Dalam pembelajaran Aqidah Akhlak bukan hanya pengetahuan saja yang ditekankan melainkan penanaman sikap atau perilaku yang baik juga diajarkan dalam mata pelajaran tersebut. Mata pelajaran Aqidah Akhlak memiliki tujuan untuk menjadikan peserta didik dapat menerapkannya dalam kehidupan sehari-hari.

Ilmu Aqidah mengajarkan mengenai hubungan manusia dengan Allah SWT sedangkan ilmu Akhlak mengajarkan mengenai hubungan manusia dengan manusia. Pendidikan Akhlak bisa dikatakan sebagai pendidikan moral dalam pendidikan Islam. Karena dengan pendidikan Akhlak dapat menjadikan peserta didik memiliki karakter yang baik pula. Karakter yang baik akan melahirkan sifat-sifat mulia yang dimiliki oleh peserta didik. Dengan demikian, pendidikan Aqidah Akhlak ini berperan penting dalam pembentukan karakter peserta didik.

Strategi artinya suatu cara. Inkuiri berasal dari bahasa inggri, "inquiry" yang berarti pertanyaan atau penyelidikan. Strategi inkuiri adalah suatu cara yang digunakan oleh guru dalam proses pembelajaran agar siswa mampu untuk bertanya, memeriksa, dan menyelidiki sesuatu. Pembelajaran dengan strategi ini dapat mendorong siswa untuk aktif dalam mengikuti pembelajaran. Jadi Pembelajaran Inkuiri adalah pembelajaran yang melibatkan peserta didik untuk diselidiki cara berfikirnya dalam memecahkan suatu masalah dengan cara berfikir kritis dan analitis. Pembelajaran dengan strategi inkuiri merupakan pembelajaran yang berorientasi pada peserta didik, sedangkan disini guru hanya sebagai fasilitator.

Terdapat beberapa langkah yang ditempuh dalam penerapan pembelajaran dengan strategi inkuiri. Langkah-langkah tersebut diantaranya yaitu.

a. Mengemukakan atau memunculkan masalah.

b. Pengumpulan data untuk memperoleh kejelasan.

c. Pengumpulan data untuk melakukan percobaan.

d. Perumusan keterangan yang diperoleh.

e. Analisis proses inkuiri.

Karakter berasal dari bahasa Yunani, "charassein" yang berarti mengukir, membuat tajam, dan membuat dalam. Menurut Kamus Besar Bahasa Indonesia, kata karakter diartikan sebagai tabiat, sifat-sifat kejiwaan, akhlak, watak, dan budi pekerti yang membedakan antara manusia satu dengan manusia yang lainnya. Karakter adalah moralitas, kebenaran, kebaikan, 
kekuatan, dan sikap seseorang yang ditunjukkan kepada orang lain melalui tindakan.

Berdasarkan definisi itu, dapat kita pahami bahwa karakter merupakan watak dan sifat yang dimiliki oleh seseorang dan telah mengakar pada dirinya sehingga dapat dikatakan identik dengan kepribadian orang tersebut. Karakter lebih cenderung pada penilaian terhadap tingkah laku atau sikap seseorang. Jika seseorang memiliki perilaku baik dan dinilai berperilaku baik, maka orang tersebut memiliki karakter yang baik pula. Begitupun sebaliknya, apabila seseorang memiliki sikap yang kurang baik maka akan dinilai berkarakter yang kurang baik pula.

Orang yang berkarakter berarti orang yang berkepribadian, berperilaku, bersifat, bertabiat, atau berwatak. Setiap orang memiliki karakter yang berbeda-beda, tidak ada seorang pun yang mempunyai karakter yang sama. Karakter dapat dijadikan sebagai penanda bagi seseorang, apakah memiliki karakter yang baik atau memiliki karakter yang buruk. Dengan mengetahui adanya karakter maka akan lebih bisa untuk mengendalikan dalam dan berhati-hati dalam bersikap, baik dengan diri sendiri maupun orang lain dalam keadaan apapun.

Karakter merupakan suatu sikap yang telah tertanam dalam diri seorang individu. Seseorang yang telah memiliki karakter tertentu dalam bertindak dan berperilaku tidak memikirkannyaa terlebih dahulu. Jadi dilakukan secara spontan. Hal itu dikarenakan bahwa karakter telah mengakar pada diri seorang individu. Sehingga karakter dapat disebut juga sebagai suatu kebiasaan.

Pendidikan karakter sangatlah penting pada zaman sekarang ini. Terlebih dengan dirasakannuya ketimbangan hasil pendidikan yang dilihat dari perilaku lulusan saat ini, semisal korupsi, perkembangan seks bebas di kalangan remaja, narkoba, tawuran, pembunuhan, perampokan, dan pengangguran lulusan. Dengan adanya karakter yang baik dalam diri peserta didik dapat mengendalikan banyaknya tantangan atau bahaya yang ada di alam semesta ini.

Jasa Ungguh Muliawan dalam bukunya Ilmu Pendidikan Islam, menyatakan bahwa Peserta didik adalah orang yang menuntut ilmu atau disebut juga dengan pelajar, yaitu orang yang belajar. Peserta didik pada dasarnya merupakan manusia yang sedang dalam masa perkembangan dan pertumbuhan yang membutuhkan orenga lain dalam menjalani perkebangan dan pertumbuhannya tersebut. Dengan demikian, peserta didik merupakan orang yang memiliki potensi untuk dikembangkan, yang mana pengembangannya dilakukan dengan proses pendidikan. Dalam perkembangan fisik dan psikis peserta didik dalam proses pendidikan ini, terdapat beberapa kebutuhan yang harus dipenuhi, diantaranya.

a. Kebutuhan jasmani, berupa kegiatan olahraga, makan, minum, tidur, pakaian, dan lain-lain.

b. Kebutuhan Sosial, berupa lingkungan, baik lingkungan sekolah maupun tempat tinggal. Dengan lingkungan seorang peserta didik akan memperoleh pengalaman belajar, yaitu dengan melakukan komunikasi dengan orang lain, baik dengan pendidik, orang tua, teman, maupun dengan masyarakat.

c. Kebutuhan Intelektual, berupa materi yang hendak dipelajari oleh siswa. Yang mana materi tersebut disesuaikan oleh minat peserta didik. Antara peserta didik yang satu dengan peserta didik yang lain memiliki minat dan bakat berbeda beda dalam memperlajari materi, dan yang suka materi sejarah, ekonomi, kimia, biologi, dan lain-lain. Minat belajar siswa tidak 
boleh dipaksakan, jadi harus sesuai

kehendak peserta didik itu sendiri.

Peserta didik bukan hanya orang yang duduk di bangku pendidikan formal, seperti sekolah atau madrasah saja, melainkan siapapun yang belajar dengan pendidik dan melakukan proses belajar disebut dengan peserta didik. Baik itu di sekolah, madrasah, masjid, pesantren, dan lain sebagainya tetap disebut sebagai peserta didik, hanya saja sebutannya yang berbeda seperti siswa, murid, santri, mahasiswa, dan lain-lain. Jadi siapa saja yang melakukan proses pendidikan itu disebut sebagai peserya didik. Dalam pendidikan tidak mengenal adanya perbedaan usia.

Menjadi seorang peserta didik tidak dibatasi oleh usia, baik itu anak kecil maupun orang tua, jika melakukan kegiatan belajar disebut juga dengan peserta didik. Seperti yang dinyatakan oleh Mangun Budianto dalam bukunya Ilmu Pendidikan Islam, bahwa peserta didik adalah setiap orang atau sekelompok orang, tanpa ada batasan usia tertentu, yang menjadi sasaran pengaruh kegiatan pendidikan yang dilakukan oleh pendidik dalam rangka tercapainya tujuan pendidikan. Jadi menuntut ilmu itu dilakukan seumur hidup tanpa ada batasan apapun, baik waktu maupun usia.

Proses penerapan strategi inkuiri dalam pembelajaran Aqidah Akhlak untuk membentuk karakter peserta didik di MI Muhammadiyah Turus tersebut bermacammacam. Diantaranya yaitu strategi ekspositori, active learning, inkuiri, kooperatif, quantum learning, dan lain-lain. Penggunaan strategi ditentukan oleh materi yang akan dibahas.

Guru Aqidah Akhlak sekaligus guru rumpun mata pelajaran PAI lainnya di MI Muhammadiyah Turus, Yuli Anita Sari, S.Pd.I. menyatakan bahwa strategi yang digunakan dalam pembelajaran menggunakan strategi yang menyenangkan. Hal ini dimaksudkan agar peserta didik tidak bosan dalam mengikuti pembelajaran dan mudah dalam memahami materi yang diajarkan. Sehingga tujuan pembelajaran dapat tercapai dengan baik.

Salah satu strategi yang digunakan dalam pembelajaran di MI Muhammadiyah Turus tersebut yaitu menggunakan strategi inkuiri. Yang mana, strategi inkuiri merupakan strategi pembelajaran yang dapat mendorong peserta didik untuk berfikir kritis dalam memecahkan suatu masalah tertentu melalui bimbingan guru. Strategi pembelajaran ini dilakukan dengan cara guru memberikan suatu permasalahan yang harus dipecahkan oleh peserta didik.

Ada beberapa langkah yang harus ditempuh pada pembelajaran dengan metode ini. Sebagai contoh, seperti yang telah diutarakan oleh Ibu Yuli pada wawancara yang telah dilakukan oleh peneliti mengenai pelaksanaan pembelajaran Aqidah Akhlak dengan strategi inkuiri yaitu pada pembelajaran adab makan dan minum. Adab makan dan minum merupakan salah satu materi yang diajarkan pada anak kelas satu MI. Disini peneliti mengambil sampel pembelajaran Aqidah Akhlak pada anak kelas satu di MI Muhammadiyah Turus. Dalam pembelajaran Aqidah Akhlak dengan materi adab makan dan minum tersebut, guru mengajarkannya dengan menggunakan strategi inkuiri.

Langkah-langkah pembelajarannya, pertama guru mengenalkan terlebih dahulu mengenai materi tentang adab makan dan minum. Akan tetapi tidak menjelaskan dengan rinci mengenai adab makan dan minum secara detail, hanya sekedar mengenalkannya saja. Setelah itu, guru memberikan roti kepada masing-masing 
peserta didik. Namun guru sengaja menaruh roti tersebut di sebelah kiri peserta didik. Hal itu dimaksudkan untuk menguji peserta didik apakah adab makan peserta didik sudah benar atau belum.

Kemudian guru menyuruh peserta didik untuk mulai memakan roti tersebut secara bersamaan. Setelah diamati, ternyata terdapat berbagai macam variasi cara makan peserta didik tersebut. Ada peserta didik yang makan dengan menggunakan tangan kiri, ada yang mengambil makanan dengan kedua tangan, ada yang makan tidak berdoa terlebih dahulu, dan ada pula peserta didik yang mengambil makanan dengan tangan kanan lalu berdoa terlebih dahulu sebelum makan.

Guru mengetahui peserta didik mana yang adab makannya benar dan peserta didik mana yang adab makannya salah. Tetapi guru tidak langsung menyalahkan peserta didik yang adab makannya salah. Langkah yang dilakukan guru adalah dengan memberikan pertanyaan kepada peserta didik mengenai bagaimana adab makan dan minum yang benar. Selain itu guru juga memberi contoh kepada peserta didik mengenai adab makan yang benar dengan menyuruh salah satu peserta didik untuk praktik di depan kelas dan peserta didik yang lain mengamatinya. Kemudian guru memberi pertanyaan kepada peserta didik apakah adab makan yang dilakukan oleh salah satu temannya yang praktik di depan kelas tersebut benar atau salah.

Dengan menggunakan strategi inquiry dalam pembelajaran Aqidah Akhlak dapat membentuk peserta didik memiliki karakter yang baik, karena peserta didik dihadapkan dengan permasalahan yang diberikan oleh guru dan harus dipecahkan. Seorang peserta didik dapat berfikir dengan kritis untuk dapat mengetahui yang baik dan yang buruk maupun yang benar atau yang salah. Saat peserta didik dihadapkan dengan adab memakan roti, ketika itu peserta didik yang sebelumnya belum mengetahui adab makan dan minum yang benar dapat menjadi tahu.

Walaupun para peserta didik tidak diberitahu secara langsung mengenai bagaimana adab makan dan minum dengan benar. Hal tersebut adalah ciri khas dari pembelajaran inkuiri, yang tujuannya mendorong peserta didik untuk berfikir kritis dalam memecahkan permasalahan. Dengan strategi tersebut, akan menjadikan peserta didik lebih mengingat materi yang diajarkannya dengan baik karena strategi yang digunakan dengan cara praktik secara langsung. Selain itu juga dengan mencari jawaban sendiri tanpa diberi tahu oleh guru terlebih dahulu.

Strategi inkuiri dalam pembelajaran Aqidah Akhlak berkaitan dengan pembentukan karakter peserta didik. Kaitannya yaitu dengan adanya kebiasaan baik, walaupun hanya kebiasaan sederhana, seperti adab makan dan minum yang benar saja tetapi kebiasaan tersebut memiliki dampak yang besar bagi kehidupan masa depan peserta didik kelak, Ketika sejak dini peserta didik telah dibekali dengan melakukan kebiasaan yang baik, maka kedepannya peserta didik tersebut akan melakukan kebiasaan baik tersebut.

Suatu kebiasaan merupakan hal yang sangat sulit untuk dirubah. Begitu pula dengan kebiasaan yang dilakukan oleh peserta didik atau anak, jika mereka mempunyai kebiasaan yang baik, maka sampai tumbuh dewasa juga akan melakukan kebiasaan baiknya tersebut. Namun sebaliknya, jika seorang anak atau peserta didik memiliki kebiasaan yang buruk, maka ketika menginjak dewasa orang terbut juga akan memiliki kebiasaan yang buruk. Akan 
tetapi tidak menutup kemungkinan dapat terjadi perubahan pada individu seseorang.

Karakter yang telah tertanam dalam diri peserta didik dapat berubah, hal itu dikarenakan adanya pengaruh faktor dari luar, seperti faktor keluarga maupun lingkungan tempat tinggal, dan lain-lain. Lingkungan tempat tinggal sangat berpengaruh terhadap pembentukan karakter peserta didik apalagi keluarga. Keluarga merupakan pihak yang sangat mempengaruhi pembentukan karakter peserta didik. Adanya pendidikan atau pengajaran tanpa adanya dukungan dan kerjasama antara pihak sekolah dan keluarga akan sulit dalam mencapai tujuan yang hendak dicapainya. Untuk itu harus ada kerjasama antara pihak sekolah dan pihak keluarga, terutama orang tua siswa dalam proses pembelajaran di sekolah.

Karakter baik peserta didik yang terbentuk dari sesuatu yang sederhana, seperti adab makan dan minum dengan benar akan berdampak besar pada kehidupannya yang akan datang kelak. Ketika seseorang telah memiliki karakter yang baik, secara spontan seseorang tersebut akan melakukan perbuatan yang baik pula tanpa berfikir yang panjang terlebih dahulu ketika hendak melakukannya. Seseorang yang telah memiliki karakter, karakter tersebut telah tertanam dalam jiwanya dan akan sulit untuk mengubahnya.

Begitu pula untuk orang yang mempunyai karakter buruk. Seseorang yang memiliki karakter buruk secara spontan akan melakukan perbuatan yang buruk pula, walaupun pada kenyataannya seseorang tersebut masih memiliki hati nurani yang sebenarnya ingin berbuat baik. Dan tak lain, bahwa orang tersebut karakternya juga telah tertanam dalam dirinya. Sehingga sulit untuk mengubahnya. Dengan demikian, karakter yang baik haruslah ditanamkan sejak dini kepada peserta didik. Bukan hanya kepada peserta didik, akan tetapi karakter juga harus ditanamkan pada anak-anak melalui bimbingan dari orang tua.

Apabila karakter baik telah melekat pada diri peserta didik, maka hal tersebut dapat mencegah adanya dampak buruk bagi masa depan peserta didik tersebut. Mengingat adanya perkembangan zaman yang semakin cepat dan berdampak negatif bagi peserta didik apabila tanpa dibentengi dengan karakter yang baik. Maka dari itu, pembentukan karakter sangat penting ditanamkan sedini mungkin.

\section{Kesimpulan}

Penelitian mengenai penggunaan strategi inkuiri dalam pembelajaran Aqidah Akhlak ini bertujuan untuk mengetahui apakah dengan strategi inkuiri tersebut dapat membentuk karakter peserta didik atau tidak. Pembelajaran Aqidah Akhlak dengan strategi inkuiri dapat membentuk karakteristik peserta didik. Karakteristik peserta didik dapat terbentuk karena dalam proses pembelajaran Aqidah Akhlak menekankan pada perilaku peserta didik dan pembelajarannya dilakukan dengan menarik, yaitu dengan menggunakan strategi inkuiri.

\section{Daftar Acuan}

AB, Said. 2016. Pengaruh Metode Pembelajaran Inkuiri pada Subtema Gerakdan Gaya Terhadap Hasil Belajar Siswa Kelas IV SDN 16 Banda Aceh. Jurnal Pesona Dasar Vol.3, No.4.

Budiyanto, Mangun. 2013. Ilmu Pendidikan Islam. Yogyakarta: Penerbit Ombak.

Hartono. 2014. Pendidik dan Peserta Didik dalam Perspektif Filsafat Pendidikan Islam. Jurnal Potensia Vol. 13 Edisi 1. 
Kesuma, Dharma, dkk. 2011. Pendidikan Karakter: Kajian Teori dan Praktik di Sekolah. Bandung: Remaja Rosdakarya.

Majid, Abdul dan Dian Andayani. 2011. Pendidikan Karakter Perspektif Islam. Bandung: Remaja Rosdakarya.

Muliawan, Jasa Ungguh. 2015. Ilmu Pendidikan Islam: Studi Kasus Terhadap Struktur Ilmu, Kurikulum, Metodologi, dan Yaumi, Muhammad. 2014. Pendidikan Kelembagaan Pendidikan Islam. Jakarta: Rajawali Pers.
M, Ramli. 2015. Hakikat Pendidik dan Peserta Didik. Jurnal Tarbiyah Islamiyah Volume 5, Nomor 1.

Suyadi. 2013. Strategi Pembelajaran Pendidikan Karakter. Bandung: Remaja Rosdakarya.

Wibowo, Agus. 2013. Managemen Pendidikan Karakter di Sekolah (Konsep dan Praktik Implementasi). Yogyakarta: Pustaka Pelajar.

Karakter: Landasan, Pilar, \& Implementasi. Jakarta: Kencana. 